DOI: https://doi.org/10.15407/techned2018.05 $: 112$

\title{
PULSE POWER SUPPLY FOR MICRO RESISTANCE WELDING WITH THE LINK OF POWER REGULATION IN CONTINUOUS MODE
}

Journal

Publisher

ISSN

Issue

Pages
Tekhnichna elektrodynamika

Institute of Electrodynamics National Academy of Science of Ukraine 1607-7970 (print), 2218-1903 (online)

No 5, 2018 (September/October)

$112-115$

\section{Authors}

Ye.V. Verbytskyi ${ }^{\star}$, O.F. Bondarenko**, Yu.V. Bondarenko***, V.O. Didenko***

National Technical University of Ukraine "Igor Sikorsky Kyiv Polytechnic Institute", pr. Peremohy, 37, Kyiv, 03056, Ukraine, e-mail: bondarenkoaf@gmail.com

* ORCID ID : http://orcid.org/0000-0001-7275-5152

** ORCID ID : http://orcid.org/0000-0002-4276-1145

*** ORCID ID : http://orcid.org/0000-0002-1803-0684

**** ORCID ID : http://orcid.org/0000-0003-2091-2069

In this paper, a topology of pulse power supply for micro resistance welding machine with the link of power regulation in continuous mode is suggested: the pulse converter generates the main part of the output power, when the small-power linear converter compensates the pulsations. The mathematical models of the circuit principal units are created. The high accuracy of welding pulses generation of power supply is confirmed through simulation. It is shown that the power pulsation in load is more than five times reduced, while the high efficiency of the power supply is kept. References 5 , figures 5 . 
Key words: micro resistance welding, pulse power supply, continuous control mode, modular structure.

Received: 05.03 .2018

Accepted: 03.05 .2018

Published: 16.08 .2018

\section{References}

1. Ataush V.E., Leonov V.P., Moskvin E.G. Micro Resistance Welding in Instrument Making. Riga: RTU, 1996. 332 p. (Rus)

2. Bondarenko Yu.V., Sydorets V.M., Safronov P.S., Bondarenko O.F. The evaluation of current regulation accuracy of multi-cell-type transistor converter with combined control. Tekhni chna Elektrodynamika

. 2012. No 2. Pp. 67-68. (Ukr)

3. Brown L.J., Lin J. Power Supply Designed for Small-Scale Resistance Spot Welding. Weldin g Journal

. 2005. Vol. 84. No 7. Pp. 32-36. URL:

https://app.aws.org/wj/2005/07/032

4. Salem M. Control and Power Supply for Resistance Spot Welding (RSW). Electronic Thesis and Dissertation Repository. Paper 130. University of Western Ontario, 2011. URL: http://ir.lib. uwo.ca/etd/130

5. Wang S.C., Wei P.S. Modeling Dynamic Electrical Resistance During Resistance Spot Welding. Journal of Heat Transfer. 2001. No 3 (123). Pp. 576-585.

PDF 